\title{
Research on Socialization Problems of Endowment Insurance in China You-Lian GUO
}

Tianjin Vocational Institute, Tianjin, China

guoyoulian2010@163.com

Keywords: endowment; endowment insurance; endowment insurance socialization; unified management

\begin{abstract}
With the rapid growth of aging population in our country, the socialization of endowment insurance is particularly important. The main problems that endowment insurance socialization faces are: the large salary gap between civil service, public Institution and business company; a considerable distance of the endowment coverage from universal coverage; shortage of endowment insurance funds; the social insurance fund supervision lacking a unified regulatory system and the risk of insecurity, appreciation of social insurance funds facing difficulties; unreasonable regulations of household registration in transferring social insurance, the lag of designing social insurance top-level system. In the regard, this paper puts forward suggestions on the main issues of endowment insurance socialization.
\end{abstract}

\section{With the Rapid Growth of Aging Population in Our Country, The Socialization Of Endowment Insurance Is Particularly Important.}

According to the fifth census, the population aged 60 in 2000 accounted for $10 \%$ of the total population, which in accordance with international standards reveals that China has turned to the aging society in 2000, while the sixth census in 2010 shows that the population aged 60 took the percentage of 13.26\%. According to the report from Xinhua News Agency, by the end of 2014 there had been over 21242 elderly population aged 60, which was $15.5 \%$ of the total population, and 24 million people aged 80 or older, 23 million low-income elderly. Taking account of the rate that In China annually there is 3 percent of the total population stepping into the rank of the elderly, the aging peak is upcoming in 10 to 20 years. By the mid-century, there will be an old person in every three people; aging growth will be a rapidly growing trend. Compared with Western countries, China has short time of aging, only in a few decades, featured by aging before getting rich, while Western countries has slow rate of aging, characterized by being rich first and then aging. Under the underdeveloped condition of China's economy, how can we cope with the aging peak is an urgent problem to be solved.

\section{The Main Issues in Endowment Insurance Socialization}

\section{The Pension Gap between Civil Servants, Public Institutions and Enterprises Employees' Retirement Dual Pension Is Too Large.}

Since 1951 China has established employee retirement system for the civil service, institutions and enterprise employees retirement benefits, which should be the same. In fact, now our country implement the two double-track lines, which means enterprise employees receive social insurance after retirement, but civil servants and employees of public institutions receive state pension; enterprise employees receive a retirement pension which is $40 \%$ to $60 \%$ of service revenues, while the state finance civil servants, public institutions receive the insurance of pension which is $80 \%$ to $90 \%$ of the service revenues; for a long time enterprise employees have paid pension insurance, but civil servants and public institutions employees never pay pension insurance; pension paid by the state financial enterprises and enterprise employees to issue civil servants, public institutions employee pensions; not only retired enterprise employees and civil servants, public institutions employees retirement benefits far and, indeed, to create value for the country's front-line employees 
are civil servants, public institutions of exploitation of workers, which is one of the root causes of social conflicts triggered.

\section{A Considerable Distance of the Endowment Coverage from Universal Coverage}

Since the reform and opening up, the State Council has attached great importance to the establishment of the pension insurance system. After entering the new century, the basic shape of the system to achieve a combination of account basic pension insurance system formed; in 2009 and 2011, a new farmers' and citizen insurances respectively got piloted, achieving full coverage of the two system in 2012 s, the formation of urban and rural old-age insurance system; by the end of 2013, the country's total number of insured people is 820 million, of which 322 million people are urban workers, and 498 million people are rural residents, with the population of receiving pension is 218 million, and the basic pension coverage is 79.7\% ; our country in a short time built up a pension insurance scheme. Despite achievements, there is still a great distance from the full coverage; there are currently more than 200 million drifted away from our pension system, which includes more than 200 million farmers and urban unemployed population, small enterprises workers. In 2013 they participated in the basic pension insurance, but 36043 people cannot afford the cost and fail to continue. This population is the highest in recent years. To achieve universal insurance, efforts are still needed.

\section{Shortage of Endowment Insurance Funds}

According to official statistics from the Social Security Ministry, China's social funds from both total revenue and total expenditure afterwards, or from the accessible income afterwards, have no gaps. In 2013 Endowment Insurance data shows that employee pension insurance total revenue of nearly 2.25 trillion yuan, 1.84 trillion yuan spending, current balance is more than 4,000 billion yuan. Pension overall level is not high, it is difficult to adjust between the province and the province. If calculated by province, in 2013 there are 19 provincial pension fund income over expenditure, balance of payments gap totaled 170.2 billion yuan, the country afterwards there is no gap, there are gaps in provincial afterwards. December 23, 2013, by the Academy of Social Sciences, "China's national balance sheet" discussion group issued "China National Balance Sheet 2013", estimates and forecasts of the 2010-2050 years pension payments situation. The results show that, if it continues to enforce existing pension system to a nationwide basic pension, in 2023 income will go beyond expenditure, making a financing gap. According to the Chinese Academy of Social Sciences, "China Pension Development Report 2015" released in Beijing. Reports said at the end of 2014, personal accounts of urban basic pension insurance have accumulated to 4.0974 trillion yuan, while urban basic pension insurance fund accumulated to over 3.18 trillion yuan. That is to say , even if all surplus fund of urban basic pension insurance are used to fill personal account, there still be close to 1 trillion empty account, and unbalance between income over expenditure in 23 provinces.

\section{The Risk of Insecurity in Managing the Social Insurance Fund And Difficulties In Appreciation of Social Insurance Funds}

China's current social insurance fund is not managed by unified management agencies, which is decentralized. Excessive layers of management lead to inefficient management; Secondly, so far China has no unified legal system of social insurance funds management, leading to a illegal basis for social insurance funds; management of social security funds brings chaos, as well management of social security funds brings about unsafe risks; on behalf of the law to the government social security funds misappropriation case in recent years have occurred; management of social security funds in relation to retired workers living and standard of living conditions, relations to social stability; the current social security funds in capital markets and inflation under imperfect conditions, increasing the value of social security funds facing dilemma: on the one hand the social security funds to buy government bonds and bank deposits, inflation will only make social security funds devalued; another On the one hand the social security funds into the capital market, low safety factor, bear the investment risk of failure. Our current basic pension surplus is only 2.4 trillion to buy government bonds and bank deposits, the rate of return is lower than inflation in the 
devaluation. Therefore, in the current economic form, how to make the social security fund in the case of ensuring security and increasing the value-added is not only important and difficult management of social security funds.

\section{Unreasonable Regulations of Household Registration in Transferring Social Insurance, and Unfairness in Transferring Premium.}

According to the Article VI of " the State Council notice on forwarding Interim Measures of transferring enterprise employees' basic endowment insurance relationship from the Ministry of Human Resources and Social Security" issued in 2009, those whose basic endowment insurance relationship is not in residence, but having made accumulative payment for 10 years, can receive it in this manner, and enjoy the local basic insurance. Under this provision: if the corporate employees' domicile is not the same as the location of the basic endowment insurance, and the payment period is less than 10 years, they cannot receive the salary there; However, the existing provisions stop the post-retirement payment from continuing, receiving procedures from implementing, and migrant workers who are over retirement age from continuing to pay basic pension insurance, contributing to being unable to enjoy endowment pension without reaching the prescriptive years. Meanwhile, even the social security funds are allowed to transfer off-site, there is no explicit plan. And It is really a dilemma whether make the transfer according to high levels of payment level or low level under the large current situation. Taking Shanghai as an example, high levels of 15 years' payment transferred to the west domicile, it will execute the payment levels in Western area. But, how the 15 years' high level of payments before can be calculated, if the endowment insurance is calculated according to the standard of the residence. There is no doubt that part of 15 years' high levels of payment before in Shanghai will be confiscated in vain, which is unfair to payer. This is the practical problem to be solved at present.

\section{Suggestion on Socializing Issues of Endowment Insurance}

\section{Retirement Benefits of Civil Servants, Public Institutions Employees and Enterprise Employees Should Be Unified.}

Retirement benefits of civil servants, public institutions employees and enterprise employees should be unified. The principle of the merger is to resolve fair treatment issues between civil servants, retired enterprise employees and retired enterprise employees. But the existing two-track system performs different STANDARDS to retirees of different departments. The gap of income is very distinct, which is a clear violation of the right to a fair pension. Especially since the implementation of the retirement pension dual-track system, it causes significant and unreasonable situation of unequal wages, which are contrary to the spirit of the Constitution. Secondly, steadily pushing forth the pension reform of the public institutions and enterprises is to avoid differentiation between public institutions and enterprise and new social injustice; meanwhile make civil servants and public employees unify into a basic pension insurance system; the public institutions and enterprises are unified to pay the basic pension insurance, but also in accordance with the business model propulsion workers, which should be clear by both employers and employees payment law. Civil servants, workers and institutions participate in the pension insurance program, which should be carried out respectively, old people in old methods, young people in new approach, and some interim ways; thirdly, the state makes a timetable to allocate funds so as to increase pensions for enterprise retirees. We must first solve the retirement wages of 700,000 retirees after implementing the new approach before 1993. They laid the foundation for China's economic development, made indelible contribution to the economy for us, so we should repay them for their laying the foundation for the development of the debt, as well fill the unreasonable wage gap since 1993. Since 2015 they began to have the equal payment for equal work. Then our country should develop a standard for wage adjustments of enterprise retirees as soon as possible. The standard adjustment should take the reference with the same standard's trades, so that enterprise workers and public organizations employees have the unified pension to the same standard. At the same time, according 
to the national economic growth rate, companies annuities and pensions of organizations and institutions keep pace with the growth of enterprises and institutions.

\section{Continuously Expanding the National Pension Coverage, Implementing Overall Management of Pension Insurance.}

"the key of the national Pension co-ordination is to establish a good incentive." An underlying meaning of co-ordination is mainly financial, personal income tax and unified social pension insurance individual payments to form a national pension. Thus, even if people of low income do not pay pension insurance, it is possible to get a basic pension, which is essentially equivalent to the new rural social pension insurance for urban residents, but its level will be further enhanced. By the end of 2013, the country has established a unified urban and rural pension insurance system in at least 15 regions. On February 2014, the State Council issued "views on the establishment of a unified basic pension insurance system for urban and rural residents " to establish a unified basic endowment insurance system for urban and rural residents in the country. By the end of March, the number of pension insurance of urban and rural residents has reached 49669 million, actually 13903 people receive treatment, payment and more raised the grade and basic pensions. National legislation in the form of passing through the residents enjoy the basic endowment social insurance benefits. In other words, there are 36043 people who cannot afford to pay fees in 2013, and more than 200 million did not participate in the basic endowment insurance including farmers, urban unemployed population, small business insurance workers who can enjoy the basic endowment insurance. Incentive system makes more benefits from more payment, longer benefits for longer payment, which is the focus of current research issues.

\section{Accumulating Finance on The Basis of the Multi-Channel National Fiscal Transfers, Making Up for the Social funding Gap.}

First, the national fiscal transfers mainly increase investment in social security funds from the developed countries, $30 \%$ to $50 \%$ of the state funds are for social security funds. There is a considerable gap between the financial transfer of funds for social security and the developed countries. The state social security funds should be designed on the basis of the top-level financial transfer. Second, public services, state-owned enterprises, monopoly profits should be used to enrich the social security funds. Some public services, such as highway toll can be gradually transferred to the social security fund accounts in order to enrich the social security fund accounts; state-owned enterprises, monopoly profits can be used to enrich the social security funds, such as the annual net profit of state-owned financial enterprises in more than 4 trillion, according to $15 \%$ deposit bonus, which can enrich the social security fund by 600 billion yuan per year. Third, the use of state-owned assets in enriching the social security fund. State-owned shares through the improvement of relevant policies, allocation of some state-owned assets to augment the country's social security funds, such as state-owned shares of listed companies retroactive portion transferred to the social security funds. Fourth, raising social security funds from the social welfare undertakings, such as encouraging the private sector and individual donations to raise social security funds; issue lottery in public to raise social security funds; raise social security funds through the organization of large public events.

\section{Steadily Achieving Appreciation of Endowment Finance under Supervision in Accordance with the Law.}

First, the national social security fund regulatory system established by law, by regulations, construction supervision system and regulatory agencies, according to the investment of social security funds conduct unified supervision, so that public social security funds, to operate under transparent; to ensure the safety of the social security fund accounts. Second, the social security fund accounts in the premise of security, to learn Western countries, the establishment of specialized investment institutions, investment experts from the institutional investors to invest in investment fund management. Third, the purpose of the social security fund investment is the value, in advance by the state social security fund investment rate of return will be set if the actual rate of return is 
lower than the yield of social security funds previously set, regulators should take measures to feasibility of experts to assess the investment of social security funds, to ensure the effective value of the investment of social security funds. Fourth, broaden the social security fund investment channels, rich investment products. Broaden the investment channels not only reduces the risk of investment, But also to increase the liquidity of investment funds, with the improvement of investment funds regulatory regime, reasonable investment should be the first high-yield investment. Fifth, optimize investment structure, focusing on long-term capital investment, gradually reduce the social security funds to buy government bonds and only the risks of banks. Sixth, the steady improvement in social security funds to invest liquidity, liquidity refers to the social security fund to invest social security funds under the protection of earnings, ready cash to pay the ready to respond to the needs of social security, not only to protect the daily needs of the social security payments, and at any time able to respond to the needs of emergency payments. Finally, do social security fund investment security, profitability, liquidity unity.

\section{On the basis of Aunified National Basic Endowment Insurance, Implementing the Transfer of Endowment Insurance through the Top-Level Design.}

First determine a unified national basic pension insurance, life abolish the household registration restrictions, to achieve the basic old-age insurance to develop a unified site transfer, so that migrant workers and other mobile workers the full enjoyment of the rights of the insured; in the realization of basic pension insurance, the top-level design and implementation of supplementary pension off-site transfer; second, remote areas pay high transfer fees low, remote part of the high personal contribution overpaid, personal income workers belong, cannot be in vain confiscated by personal choice extraction, can also be added as a personal account transfer; unit overpayment from the top part of the country should be part of the design with individual supplementary pension accounts transfer part can be confiscated. Third, the top-level design pension pay points to calculate age segment calculation, that pay high pension age segment to calculate high, low pay in lower pension calculation section, and finally the design of a water shed pensions.

\section{References:}

[1]Hong Lan LI, Yuning Wu cope with the aging of Pension StrategiesAging scientific December 2013 Section 7

[2].Chuan Jiang Xiao, haiya Liao China Urban Pension Insurance System: Historical Evaluation, Reality and Solutions Insurance Research 201210

[3] Beibei Ma,Yueling Zhang ,shu Fang Du authority pension reform institutions Insurance System problem and Countermeasures Vocational College in June 2011 Section 3

[4]. Guo and Lin on urban social pension insurance system of Conception Economic Forum 20007

[5] Zhou Cong of fund management institutions of social security and taxation aspect Strategies 201220 